Article

\title{
Life Cycle Assessment Framework for Embodied Environmental Impacts of Building Construction Systems
}

\author{
Mona Abouhamad (D) and Metwally Abu-Hamd * \\ Faculty of Engineering, Cairo University, Giza 12613, Egypt; m.abouhamad@eng.cu.edu.eg \\ * Correspondence: abuhamd@eng.cu.edu.eg
}

Citation: Abouhamad, M.; Abu-Hamd, M. Life Cycle Assessment Framework for Embodied Environmental Impacts of Building Construction Systems. Sustainability 2021, 13, 461. https://doi.org/10.3390/su13020461

Received: 28 November 2020 Accepted: 31 December 2020 Published: 6 January 2021

Publisher's Note: MDPI stays neutral with regard to jurisdictional clai$\mathrm{ms}$ in published maps and institutional affiliations.

Copyright: $\odot 2021$ by the authors. Licensee MDPI, Basel, Switzerland. This article is an open access article distributed under the terms and conditions of the Creative Commons Attribution (CC BY) license (https:// creativecommons.org/licenses/by/ $4.0 /)$.

\begin{abstract}
This paper develops a life cycle assessment framework for embodied environmental impacts of building construction systems. The framework is intended to be used early in the design stage to assist decision making in identifying sources of higher embodied impacts and in selecting sustainable design alternatives. The framework covers commonly used building construction systems such as reinforced concrete construction (RCC), hot-rolled steel construction (HRS), and light steel construction (LSC). The system boundary is defined for the framework from cradle-to-grave plus recycling and reuse possibilities. Building Information Modeling (BIM) and life cycle assessment are integrated in the developed framework to evaluate life cycle embodied energy and embodied greenhouse emissions of design options. The life cycle inventory data used to develop the framework were extracted from BIM models for the building material quantities, verified Environmental Product Declarations (EPD) for the material production stage, and the design of construction operations for the construction and end-of-life stages. Application of the developed framework to a case study of a university building revealed the following results. The material production stage had the highest contribution to embodied impacts, reaching about $90 \%$. Compared with the conventional RCC construction system, the HRS construction system had $41 \%$ more life cycle embodied energy, while the LSC construction system had 34\% less life cycle embodied energy. When each system was credited with the net benefits resulting from possible recycling/reuse beyond building life, the HRS construction system had 10\% less life cycle embodied energy, while the LSC construction system had $68 \%$ less life cycle embodied energy. Similarly, the HRS construction system had 29\% less life cycle greenhouse gas (GHG) emissions, while the LSC construction system had $62 \%$ less life cycle GHG emissions. Sustainability assessment results showed that the RCC construction system received zero Leadership in Energy and Environmental Design (LEED) credit points, the HRS construction system received three LEED credit points, while the LSC construction system received five LEED credit points.
\end{abstract}

Keywords: embodied energy; embodied greenhouse gas emissions; life cycle environmental assessment; building information modeling; building construction systems; sustainability assessment

\section{Introduction}

The total life cycle energy consumed by a building is classified into operational energy and embodied energy. Operational energy is defined as the energy utilized in the use stage of the building, while embodied energy is the total amount of non-renewable primary energy required for all direct and indirect processes related to the construction of the building, its maintenance and end of life. Similarly, the embodied greenhouse gas (GHG) emissions are the embodied carbon dioxide equivalent of greenhouse gases (carbon dioxide $\left(\mathrm{CO}_{2}\right)$, methane $\left(\mathrm{NH}_{4}\right)$, nitric oxide $\left.\left(\mathrm{N}_{2} \mathrm{O}\right)\right)$, which are emitted over the life cycle of the building. The Global Warming Potential (GWP) is defined by The Intergovernmental Panel on Climate Change (IPCC) [1] as a relative measure of how much a given mass of GHG is estimated to contribute to global warming over a time scale of 100 years. 
The construction industry accounted for 39\% of energy and process-related GHG emissions in 2018, 11\% of which resulted from manufacturing building materials and products such as steel, cement, and glass [2]. Embodied energy and GHG emissions originating from buildings and construction account for nearly $20 \%$ of the world's energy consumption and GHG emissions [3]. The world emitted 33 gigatons of carbon dioxide equivalent $\left(\mathrm{CO}_{2} \mathrm{eq}\right)$ in 2019 with an average share of $4.3 \mathrm{t} \mathrm{CO}_{2} \mathrm{eq}$ per capita [2]. On the national level, Egypt's economic development and increasing population are contributing to increased GHG emissions. Its fossil fuel-based power and transport sectors are among the most carbon intensive [4]. Egypt emitted 310 million $\mathrm{t}$ of $\mathrm{CO}_{2} \mathrm{eq}$ GHG emissions in 2016 with a share of 3.29 t $\mathrm{CO}_{2}$ eq per capita/year [5]. The increase in GHG emissions has so far caused a global warming of $1^{\circ} \mathrm{C}$ above pre-industrial levels [6]. Under current policies, global warming is expected to reach a range of $3.1-3.7^{\circ} \mathrm{C}$ above pre-industrial levels by 2050, since the world's building stock is forecasted to double in size to house a global population of 11 billion. The United Nation's Conference of Parties adopted in 2015 the Paris Agreement to take all necessary measures to limit global warming to $1.5^{\circ} \mathrm{C}$ above pre-industrial levels [7]. The IPCC [8] stated that reaching that target would require rapid, far-reaching, and unprecedented changes in all aspects of society. The IPCC recommended that the " $1.5^{\circ} \mathrm{C}$-consistent pathways require building GHG emissions to be reduced by $80-90 \%$ by 2050 , new construction to be fossil-free and near-zero energy by 2020". The IPCC also highlighted the need for "an increased rate of energy refurbishment of existing buildings to 5\% per annum in OECD countries". An enhanced construction would influence $42 \%$ of final energy consumption, about $35 \%$ of GHG emissions, and more than $50 \%$ of all extracted materials [6]. The goals adopted by the United Nation in the new 2030 global agenda for sustainable development ([9] include achieving sustainable consumption and production and building sustainable communities).

Therefore, the construction industry must minimize the consumption of both embodied and operational energies to achieve a sustainable built environment. Efforts to reduce building energy and GHG emissions have so far concentrated on reducing operational energy consumption and increasing the use of renewable energy resources. As operational energy consumption is reduced, embodied energy and GHG emissions will contribute significantly to the effort to reduce the environmental impact of buildings and accomplish the target set by the IPCC and the United Nation. Therefore, societies have started to re-assess the construction industry in order to achieve more environmentally efficient buildings by considering the important balancing act between the three pillars of sustainability: economic, environmental, and social constraints in the selection of building materials and building structural systems. On the economic level, building designers must explore new construction methodologies and create innovative building construction systems that have the potential to produce more efficient buildings. On the environmental level, these systems must also be environmentally friendly in terms of material use, embodied energy, and embodied GHG emissions.

The construction systems commonly used in buildings are reinforced concrete construction (RCC) (Figure 1a) or hot-rolled steel construction (HRS) (Figure 1b). In both cases, floors are composed of cast-in-situ reinforced concrete slabs, and the walls are built from bricks. Recently, light (cold-formed) steel construction systems (LSC) (Figure 1c) have proven to be an efficient alternative to conventional building construction systems for low and medium-rise buildings used in residential, office, and commercial applications [10-12]. Timber construction systems may also be used in some countries where their cost is inexpensive. 


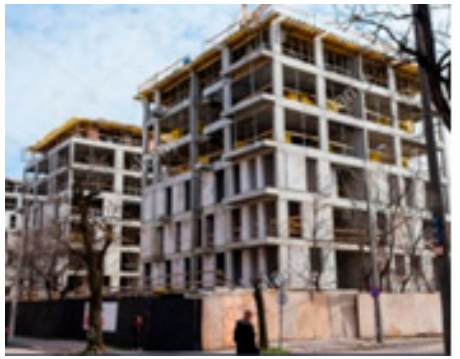

(a)

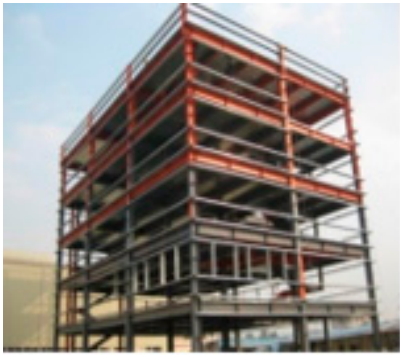

(b)

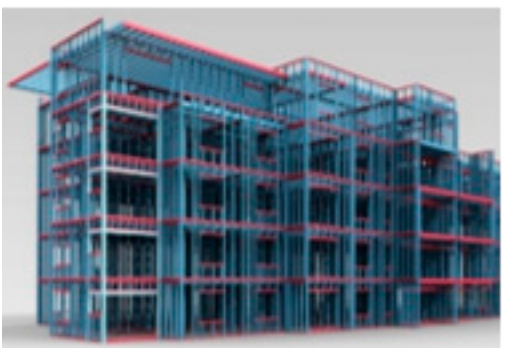

(c)

Figure 1. Commonly used construction systems: (a) Reinforced concrete construction, (b) Hot-rolled steel construction, and (c) Light steel construction.

Investigating the environmental impacts of alternative building construction systems is best performed using life cycle assessment (LCA) methodology. LCA is a versatile tool that can be used at a single product level to quantify the energy consumption and environmental impacts resulting from the product over its entire life cycle from cradle to grave, or at the whole building level to assess the environmental impacts of several alternate designs in order to select the design with the best environmental impact. LCA is best used to complement economic building data with measures on their environmental impacts [13] and to help take necessary actions to increase the resource efficiency of the building construction industry.

The general methodology for LCA in all sectors follows the four-stage framework recommended by ISO 14040 [14] and ISO 14044 [15]. The four stages are (i) goals and scope definition, (ii) life cycle inventory (LCI), (iii) life cycle assessment (LCA), and (iv) interpretation. The specific methodology for LCA in construction works is detailed in the European standard EN 15978 [16], which covers the environmental, economic, and social aspects of sustainability. Environmental assessment is performed according to a modular framework recommended by EN 15978 for LCA at the whole building level and by EN 15804 [17] for LCA at the product level. These standards introduced a modular concept for the definition of the system boundaries as shown in Figure 2.

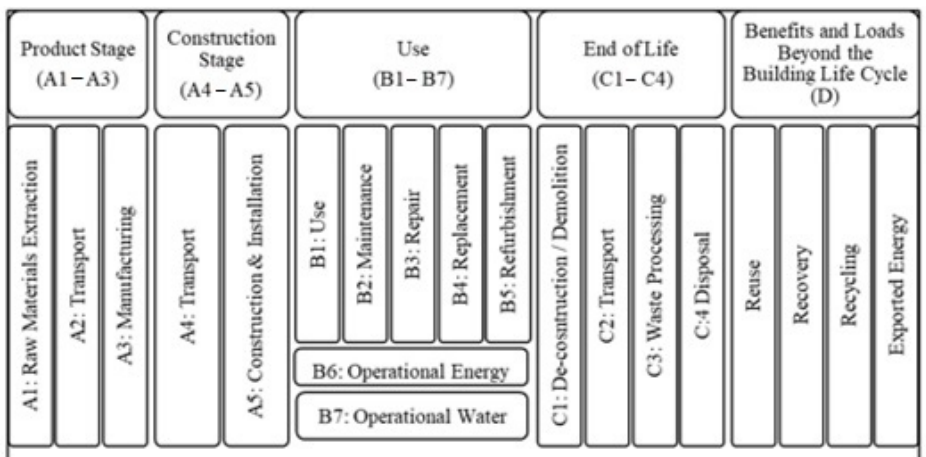

Figure 2. Modular life cycle assessment (LCA) framework (adapted from [17]). 


\section{Preliminary Research Analysis}

The Energy in Building and Communities Program (EBC) [3] presented a study of the assessment of embodied energy and $\mathrm{CO}_{2}$ eq for building construction that covered the present status of embodied energy and GHG emissions in addition to reviews of their calculation procedures and theoretical basis. Zeng and Chini [18] presented a review of research on embodied energy of buildings using a bibliometric analysis of 398 papers published from 1996 to 2015. The review pointed out the major three research areas for embodied energy to be LCA, building design, and GHG emissions. Dixit [19] presented a literature review of life cycle embodied energy in residential buildings. The inconsistencies of reported embodied energy values pointed out a need to standardize the present assessment procedure of embodied energy calculations. De Wolf et al. [20] presented a review of current industry practice related to measuring embodied $\mathrm{CO}_{2}$ eq of buildings using multiple data sources to determine the difficulties in measuring and reducing embodied GHG emissions in practice. The paper pointed out the need for improved data quality and transparent LCA procedures. Chastas et al. [21] analyzed the results of 95 case studies to identify the range of embodied carbon emissions of residential buildings and concluded that the large scatter of results confirms a need for standardization in LCA methodology. Fenner et al. [22] presented a review of current procedures for calculating the carbon footprint. They concluded that there was a need for a clear, accessible, and consistent procedure to assess the carbon emission from buildings. Rock et al. [23] analyzed more than 650 LCA case studies to investigate the global trends of life cycle GHG emissions. The analysis revealed an increase in the relative and absolute contributions of embodied GHG emissions and emphasized the necessity to reduce GHG emissions by reducing both embodied and operational impacts. Birgisdottir et al. [24] presented the findings from a major five-year research project sponsored by the International Energy Agency (IEA). The project investigated the reduction of embodied energy and GHG emissions over the whole life of buildings. Annex 57 of the project collected and analyzed over 80 detailed quantitative and qualitative building case studies from the contributing countries. Simonen et al. [25] developed a database of building embodied carbon that contains over one thousand buildings. The study concluded that the initial embodied carbon of the low-rise residential building's structure, foundation, and enclosure is normally less than $500 \mathrm{kgCO} 2 \mathrm{eq} / \mathrm{m}^{2}$. Gervasio et al. [26] proposed a framework for the quantification of benchmarks for the environmental impacts of buildings. Based on the developed framework, the life cycle GHG emissions is equal to $5-12 \mathrm{~kg} \mathrm{CO}_{2} / \mathrm{m}^{2}$.yr, while the total primary energy is equal to $68-186 \mathrm{MJ} / \mathrm{m}^{2}$.yr. Rodrigues et al. [27] evaluated the embodied carbon and energy of an industrial building in Portugal. Their results showed an embodied carbon of $508.57 \mathrm{kgCO}_{2} / \mathrm{m}^{2}$ and an embodied energy of $4908.68 \mathrm{MJ} / \mathrm{m}^{2}$.

However, the current situation of LCA of embodied impacts reveals that calculation procedures greatly vary depending on the country or researcher; accordingly, the results also differ widely [3]. Nwodo and Anumba [28] identified the major challenges in building LCA to be (a) data intensity and quality, (b) subjectivity in environmental impact characterization and valuation, (c) inadequate definition of functional units, (d) assumptions for building life span and service life, (e) lack of procedures for system boundaries, (f) lack of uncertainty analysis, and (g) limitation as a decision-making tool.

The objective of this paper aims to develop a life cycle assessment framework for embodied environmental impacts of building construction systems which overcomes these shortcomings as follows:

(a) The framework is developed according to principles stated in international LCA standards.

(b) The functional unit is selected to enable comparisons with other LCA results.

(c) The building life span and service life are selected based on structural design codes.

(d) The system boundaries are defined relative to the life cycle stages. 
The data used in the assessment are based on realistic data obtained from certified Environmental Product Declarations in the material production stage and from the design of construction operations for the construction and end-of-life stages.

The framework is intended to be used by decision makers and stakeholders early in the design stage to select the design alternative with the most sustainable design alternative that has the least embodied environmental impacts.

\section{Methodology of LCA Framework}

\subsection{Goal and Scope of LCA}

The goal of the present research is to develop a framework for the selection of building construction systems based on life cycle embodied energy and GHG emissions. The framework is intended to be used early in the design stage by designers, developers, investors, decision makers, and any other stakeholders (product manufacturers, community groups, etc.) to better inform them of the environmental impacts of different material choices and construction system alternatives. The scope of the LCA framework is defined by the system boundary which includes all life cycle from cradle to grave in addition to benefits and loads due to possible reuse or recycling. The framework covers traditional building construction systems used in residential, office, and commercial buildings with a focus on low and mid-rise applications. The period of analysis for life cycle assessment is assumed to be equal to 50 years, as suggested by the European design code EN 1990 [29].

\subsection{Life Cycle Inventory}

The life cycle inventory ( $L C I)$ phase involves the compilation and quantification of materials and energy inputs and GHG emissions output throughout the building life cycle. The developed framework uses a process-based LCI approach to calculate the energy inputs and related GHG emissions associated with the different building processes. Two sets of data are required to perform LCA; the first set contains input data related to the required quantities of building materials, while the second set contains input data related to the environmental impacts of building material and construction processes. Life cycle analysis of construction materials and buildings suffers from the unavailability of reliable and certifiable environmental information [26]. ISO 14044 suggests the following requirements for the quality of data: (i) Time-related coverage; (ii) Geographical coverage; (iii) Technological coverage; and (iv) Completeness.

The input data related to the quantities of building materials used over the building life cycle can be quite intensive. Use of Building Information Modeling (BIM) can facilitate the estimation of the required quantities for proposed design alternatives [30]. The workflow for estimating the quantities of building materials follows the steps shown in Figure 3:

1. Develop 3D structural models for the construction of system alternatives.

2. Perform the structural analysis/design of the design alternatives using available tools linked to the BIM software.

3. Utilize the BIM 5D tool link to calculate the required material quantities for each design alternative.

4. Calculate the embodied energy and embodied GHG emissions for each design alternative using the relevant life cycle inventory data. 


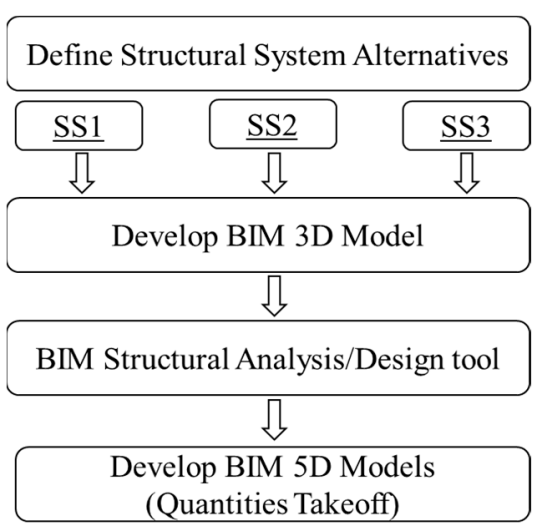

Figure 3. Workflow for calculating building materials quantities [30].

Life cycle inventory data related to environmental impacts of building materials and construction processes are usually available under two main categories (Gervasio and Dimova 2018):

(i) Generic LCI data in which the environmental data used in LCAs are based on typical material production data and construction procedures that are specific to the region where the building is to be constructed. Changes in any of these items can considerably influence the results of the assessment. The generic data available in LCI databases cannot be assumed to hold in other geographic regions where manufacturing and construction procedures may vary significantly. Generic LCI databases are usually developed by LCA consultancy companies, by academic institutions, or by industrial organizations (e.g., Worldsteel database of steel products [31]).

(ii) Specific LCI data which are provided by manufactures and producers in the form Environmental Product Declarations (EPDs). An EPD is an independently validated certificate that contains clear and comparable data about the life-cycle environmental impact of products. EPDs are constructed and registered according to ISO 14025 [32] in the framework of a program, such as the International EPD System [33]. All EPDs registered in the International EPD System are publicly available and free to download from their website. The construction industry has widely adopted EPDs as a method of reporting and sharing environmental data.

No specific data representing Egypt exist in any of the available generic LCI databases. Using the world average values may lead to incorrect results, as they may not correspond to the specific manufacturing procedures, energy mixes, building design, and construction practices employed in Egypt. In order to overcome this problem, the LCA framework in the present study was developed using specific LCI data related to different construction processes for different life cycle stages as follows:

1. In the material production stage (Modules A1 to A3): Verified EPDs having similar production conditions to Egypt were used to calculate embodied energy and GHG emissions.

2. In the construction stage (Modules A4 and A5) and end-of-life stage (Modules C1 to C4): embodied energy and GHG emissions were calculated based on the design of relevant construction operations.

\subsection{Life Cycle Impact Assessment}

This stage of LCA transforms the results of life cycle inventory into specific impact indicators that are selected according to the LCA goal. EN 15804 defines three main types of environmental indicators for LCA: (a) eight indicators related to environmental input flows such as renewable and non-renewable energy and fuels, (b) seven indicators focusing on environmental impact categories using characterization factors, such as GWP and Ozone Depletion Potential, and (c) seven indicators focusing on output flows, such as waste flows 
and materials for recycling. According to the stated goals of the present LCA framework, the following impact indicators were used in the developed framework:

1. Use of non-renewable primary energy resources expressed in Mega Joules (MJ), net calorific value.

2. GWP expressed in carbon dioxide equivalent expressed in $\mathrm{kg} \mathrm{CO}_{2} \mathrm{eq}$ using the characterization factors recommended by the IPCC [8].

\section{LCA of Embodied Energy and GHG Emissions}

\subsection{LCA in Modules A1 to A3 (Material Production Stage)}

Embodied energy and GHG emissions related to raw material extraction, production, and transportation phases were collected from EPDs provided by manufacturers and producers having production technologies and construction conditions similar to Egypt. Items for which no similar EPDs exist were inventoried based on the available literature with similar production conditions to Egypt. The results are shown in Table 1 for commonly used building materials. The procedure used to obtain the shown values is illustrated next for steel and concrete production, as they both represent the major contribution to material usage and environmental impacts. Average values of available EPDs were used for other building materials.

Table 1. Intensity of embodied energy and embodied greenhouse gas (GHG) emissions of building materials (Modules A1 to A3).

\begin{tabular}{cccc}
\hline \multirow{2}{*}{ Building Material } & Unit & Embodied Energy & Embodied GHG Emissions \\
\cline { 3 - 4 } & & $\mathbf{M J} /$ Unit & $\mathbf{k g ~ C O}_{\mathbf{2}}$-eq \\
\hline Concrete Class 20 MPa & $\mathrm{m}^{3}$ & 1755 & 255 \\
Concrete Class 30 MPa & $\mathrm{m}^{3}$ & 2070 & 335 \\
Cement Mortar & $\mathrm{m}^{3}$ & 2240 & 341 \\
Clay Brick & $\mathrm{m}^{3}$ & 4061 & 287 \\
Hot rolled steel sections & ton & 29,890 & 2710 \\
Galvanized studs & ton & 29,170 & 2280 \\
Galvanized decking & ton & 33,448 & 1689 \\
Reinforcing Steel & ton & 12,000 & 891 \\
Welded wire mesh & ton & 12,329 & 737 \\
\hline
\end{tabular}

\subsubsection{Steel Production}

The process flow diagram for typical steel production is shown in Figure 4. Steel sections are produced using some percentage of scrap steel which may vary from $0 \%$ to $100 \%$. Steel is produced in Egypt using Electric Arc Furnace (EAF) technology with a nearly $50 \%$ scrap ratio. Data from EPDs related to steel production cover a wide range of production methodologies. Therefore, energy flows related to steel production were extracted from available EPDs with similar production technologies and validated against actual data collected from major steel production companies in Egypt. Egyptian steel companies produce steel using $50 \%$ scrap, so the EPDs that use $50 \%$ scrap steel were selected to represent steel production in Egypt. The amount of GHG emissions related to electric energy consumption was adjusted to reflect the energy mix used in Egypt, which is produced using $92 \%$ natural gas and $8 \%$ fuel [34]. The corresponding GHG emission factor is $0.495 \mathrm{~kg} \mathrm{CO} 2 \mathrm{eq} / \mathrm{kWh}$. Additionally, structural steel needs to be fabricated to the exact design requirements in a steel fabrication shop before being transported to the construction site. Therefore, the energy and emission flow due to the fabrication of steel members should also be included in the material production stage. 


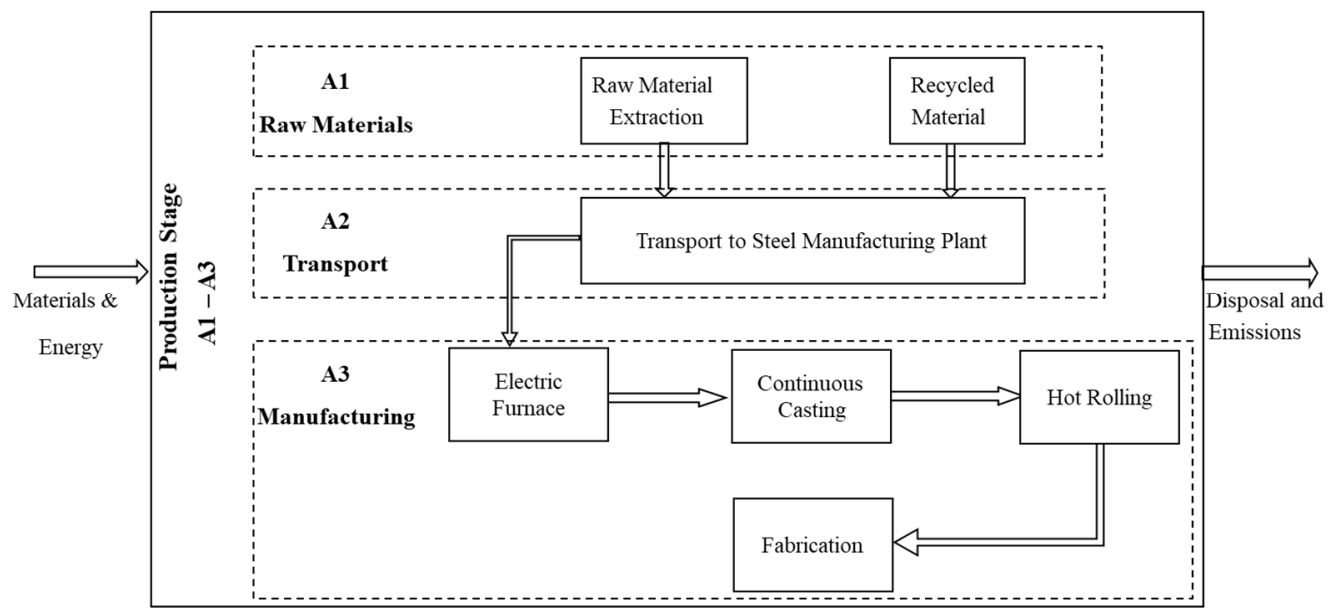

Figure 4. Process flow diagram for production of steel members (stages A1-A3).

\subsubsection{Concrete Production}

The process flow diagram for typical concrete production is shown in Figure 5. More than one type of concrete is used depending on the required design strength class. The most used strength classes are as follows. (1) Low-strength concrete has a compressive strength of $20 \mathrm{MPa}$ for plain concrete applications. The embodied energy values fall in the range $1500-1910 \mathrm{MJ} / \mathrm{m}^{3}$ with an average of $1755 \mathrm{MJ} / \mathrm{m}^{3}$ while the embodied GHG emissions fall in the range $249-257 \mathrm{Kg} \mathrm{CO}_{2}$ eq with an average value of $255 \mathrm{Kg} \mathrm{CO}_{2}$ eq. (2) The higher strength class has a minimum compressive strength of $30 \mathrm{MPa}$ used for reinforced concrete applications. Energy for the concrete production is supplied by diesel fuel and electricity. The embodied energy values fall in the range $1860-2490 \mathrm{MJ} / \mathrm{m}^{3}$ with an average of $2070 \mathrm{MJ} / \mathrm{m}^{3}$, while the embodied GHG emissions fall in the range $307-341 \mathrm{Kg}$ $\mathrm{CO}_{2}$ eq with an average value of $335 \mathrm{Kg} \mathrm{CO}_{2}$ eq.

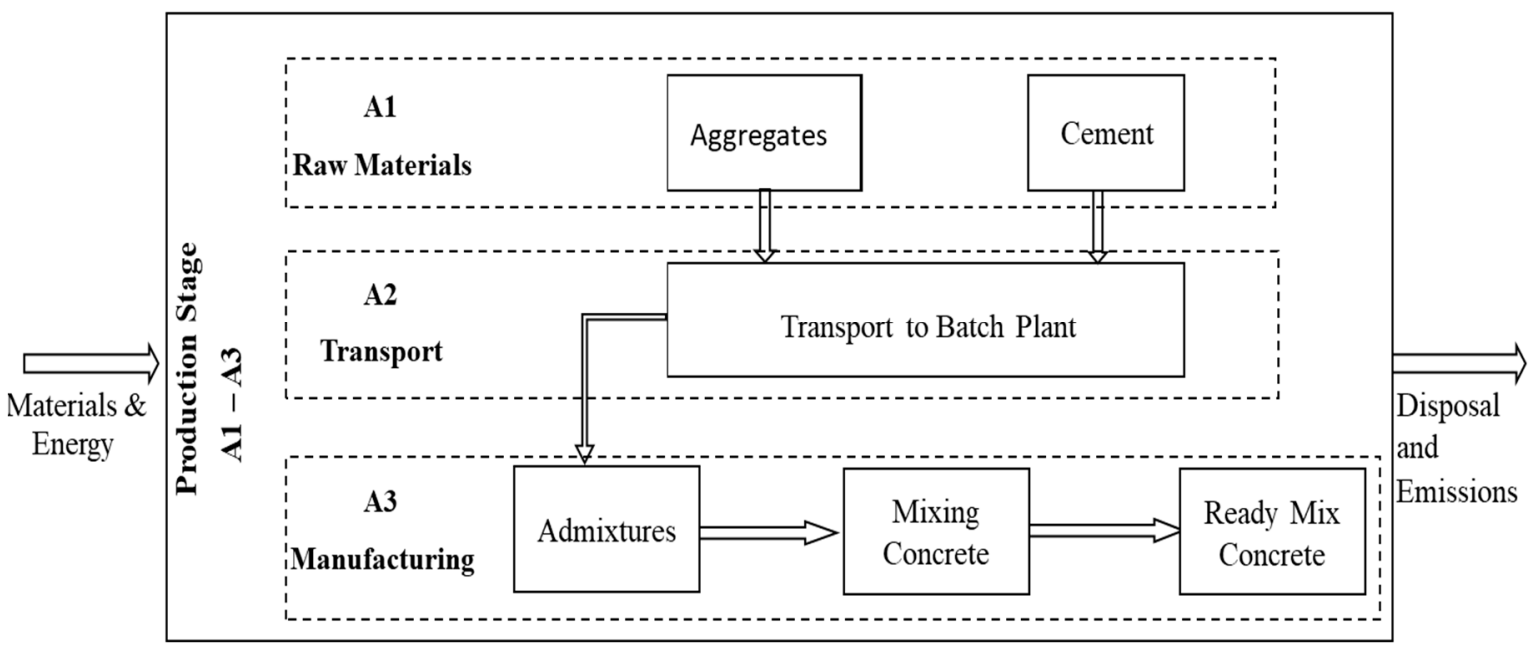

Figure 5. Process flow diagram for the production of concrete (stages A1-A3).

Concrete production in Egypt follows the same process flow using local aggregates and cement.

The associated environmental impacts were taken as the average values of similar EPDs, as shown in Table 1. 


\subsection{LCA in Modules A4 and A5 (Construction Stage)}

This stage includes the construction energy and GHG emissions due to (i) transportation to the construction site (Module A4) and (ii) the construction process (Module A5).

\subsubsection{Transportation to Construction Site (Module A4)}

This module includes the transportation of building materials from the manufacturers to the building site in addition to any excavated material to the landfills. The energy use and related GHG emissions associated with this process depend on the energy consumption of the transportation trucks and on the transportation distance. The transportation distance used in calculations is usually doubled to take into consideration the return cycle of the delivery trucks. The average fuel consumption of a typical 30-t transportation truck used in Egypt is equal to $5 \mathrm{~km} /$ liter of diesel fuel. The energy due to fuel consumption is calculated using the energy conversion factor $1 \mathrm{~L}$ of diesel fuel $=38.29 \mathrm{MJ}$. Then, the calculation of GHG emissions is performed according to the procedure of IPCC as:

$\mathrm{CO}_{2}$ emission from road transport $\left(\mathrm{kg} \mathrm{CO}_{2}\right)=$ Fuel consumed $(\mathrm{TJ}) *$ emission factor $(\mathrm{kg} / \mathrm{TJ})$.

The emission factor is equal to the carbon content of the fuel multiplied by $44 / 12$ [35]. Typical values of emission factors for diesel trucks are 74,100 for $\mathrm{CO}_{2}$ and 3.9 for $\mathrm{CH}_{4}$ and $\mathrm{N}_{2} \mathrm{O}$ [35]. The emission factor for GHG emissions is calculated from these values using the GWP characterization factor recommended by IPCC as 1 for $\mathrm{CO}_{2}, 25$ for $\mathrm{CH}_{4}$, and 298 for $\mathrm{N}_{2} \mathrm{O}$.

\subsubsection{Construction Process (Module A5)}

Embodied energy and GHG emissions arise in site construction processes from the use of different construction equipment. The construction equipment needed to construct a specific building is determined based on the design of construction operations for the building. Average fuel consumptions of different construction equipment used at the construction site are shown in Table 2 based on a survey of building contractors in Egypt. The associated energy and GHG emissions are calculated by applying the same conversion factors used in Module A4. The number of hours required for each equipment is calculated from the building material quantities of the related construction process and the productivity rate of the equipment.

Table 2. Productivity, fuel consumption, energy, and GHG emissions of construction equipment.

\begin{tabular}{|c|c|c|c|c|}
\hline \multirow{2}{*}{ Equipment } & \multirow{2}{*}{ Productivity/Hour } & $\begin{array}{c}\text { Fuel } \\
\text { Consumption }\end{array}$ & $\begin{array}{c}\text { Embodied } \\
\text { Energy }\end{array}$ & $\begin{array}{c}\text { Embodied } \\
\text { GHG Emissions }\end{array}$ \\
\hline & & Liters/Hour & GJ/Hour & $\mathrm{kg} \mathrm{CO} \mathrm{CO}_{2} \mathrm{eq} / \mathrm{Hour}$ \\
\hline Excavator & $21 \mathrm{~m}^{3}$ & 15 & 0.574 & 47.514 \\
\hline Wheel Loader & $200 \mathrm{~m}^{3}$ & 15 & 0.574 & 47.514 \\
\hline Concrete Mix Truck $10 \mathrm{~m}^{3}$ & $40 \mathrm{~m}^{3}$ & 5 & 0.191 & 15.838 \\
\hline Concrete Pump & $40 \mathrm{~m}^{3}$ & 5 & 0.191 & 15.838 \\
\hline Concrete Vibrator & $40 \mathrm{~m}^{3}$ & 5 & 0.191 & 15.838 \\
\hline Mobile Crane $20 \mathrm{t}$ & $5 \mathrm{t}$ & 5 & 0.191 & 15.838 \\
\hline
\end{tabular}

\subsection{LCA in Modules B1 to B5 (Use Stage)}

Modules B1 to B5 include all the data related to the maintenance, repair, and refurbishment of the building, which includes the usage of materials and equipment and the management of the associated waste. Environmental data for these modules should be based on the expected maintenance and repair scenarios considering the assumed design life of each building. Building materials related to the structural components of the building do not usually need to be repaired or replaced over the design life of the building. On the other hand, building materials related to finishes such as doors, windows, tiles, and paints need to be maintained over the design life of the building. Available studies [36] show that the environmental impacts associated with these modules are negligible compared to the life cycle impacts. The present LCA framework focuses on the structural components 
of the building and does not include the building materials related to finishes. Therefore, the environmental impacts associated with these modules shall be neglected without any significant effect on the outcome of LCA.

\subsection{LCA in Modules C1 to C4 (End-of-Life Stage)}

Module C1 covers all the processes in the demolition/dismantling of the building at the end of its design life and includes energy consumed in the use of equipment, fuel consumption, and related emissions. Detailed information on these processes does not usually exist at the design stage. Approximate estimates are provided by The Athena Sustainable Materials Institute [37] based on the analysis of demolition data of concrete, steel, and wood buildings. The average energy consumed in demolition was found to be equal to $0.07 \mathrm{MJ} / \mathrm{kg}$ for concrete buildings and $0.239 \mathrm{MJ} / \mathrm{kg}$ for steel buildings where recycling is usually present. Module C2 covers the transportation of the demolished/dismantled materials to landfills, waste treatment plants, or recycling plants. The environmental impacts associated with this module can be estimated using the same energy and emission factors stated in Module A4. Module C3 covers all the processes in the waste treatment plant, while Module C4 covers the processes related to the final disposal of materials. The developed LCA framework focuses on the structural components of the building for which no waste treatment is expected, and therefore, no environmental impacts for Modules C3 and $\mathrm{C} 4$ are calculated.

Building elements have several end-of-life treatments depending on the possibilities of recycling or reuse of the building material and the construction system used. For example, brick walls, reinforced concrete slabs, beams, and columns are usually disposed from building site to landfills with no re-use/recycle value. On the other hand, steel members have a very high potential for reuse/recycle. The environmental and economic aspects of sustainability require optimizing the resources and energy used in building construction. For instance, The EU Waste Framework Directive [38] calls for taking all necessary measures needed to (a) achieve a minimum of $70 \%$ of non-hazardous construction by 2020 and (b) demolition waste to be prepared for re- recycling or reuse. The Worldsteel Association [31] reports that $90 \%$ of steel section and $70 \%$ of reinforcing bars are usually recyclable. Table 3 shows the assumed end-of-life options of common building elements:

Table 3. End of life options for common building elements.

\begin{tabular}{ccccc}
\hline Building Element & Demolition/Dismantling & \% Landfill & \% Recycle & \% Reuse \\
\hline Concrete elements & Demolition & $100 \%$ & 0 & 0 \\
Steel reinforcement & Dismantling & $30 \%$ & $70 \%$ & 0 \\
Hot rolled steel members & Dismantling & $10 \%$ & $90 \%$ & 0 \\
Cold formed steel & Dismantling & $10 \%$ & $90 \%$ & 0 \\
members & Demolition & $100 \%$ & 0 & 0 \\
Brick wall & Dismantling & $30 \%$ & 0 & $70 \%$ \\
\hline
\end{tabular}

\subsection{LCA in Module D (Beyond System Boundary)}

Recycled steel is mostly reused in steel making plants to produce new steel, as shown in the allocation process flow diagram in Figure 6. In Module C1, the scrap steel with Recycle Ratio (RR) is transported to the recycling plant, while the demolition waste (1-RR) is transported to landfills. The scrap steel is combined with iron ore at the Electric Arc Furnace (EAF) in the steel-making plant to produce new steel. The net environmental impacts due to recycling or reuse are allocated to Module D according to EN 15804 [17]. The net environmental impact is equal to the difference between the impacts due to the recycling process that substitutes primary production and the impacts due to the production of the avoided primary material. The net benefits related to material and energy resources is the difference between the input and output of secondary material. The benefits and loads of the scrap steel are accounted for in Module D in accordance with the global "value of scrap" 
life cycle model [31]. Depending on the Scrap Ratio (SR), Module D allocates only the net benefit given by (RR-SR), which is the ratio of scrap used in the steel-making process.

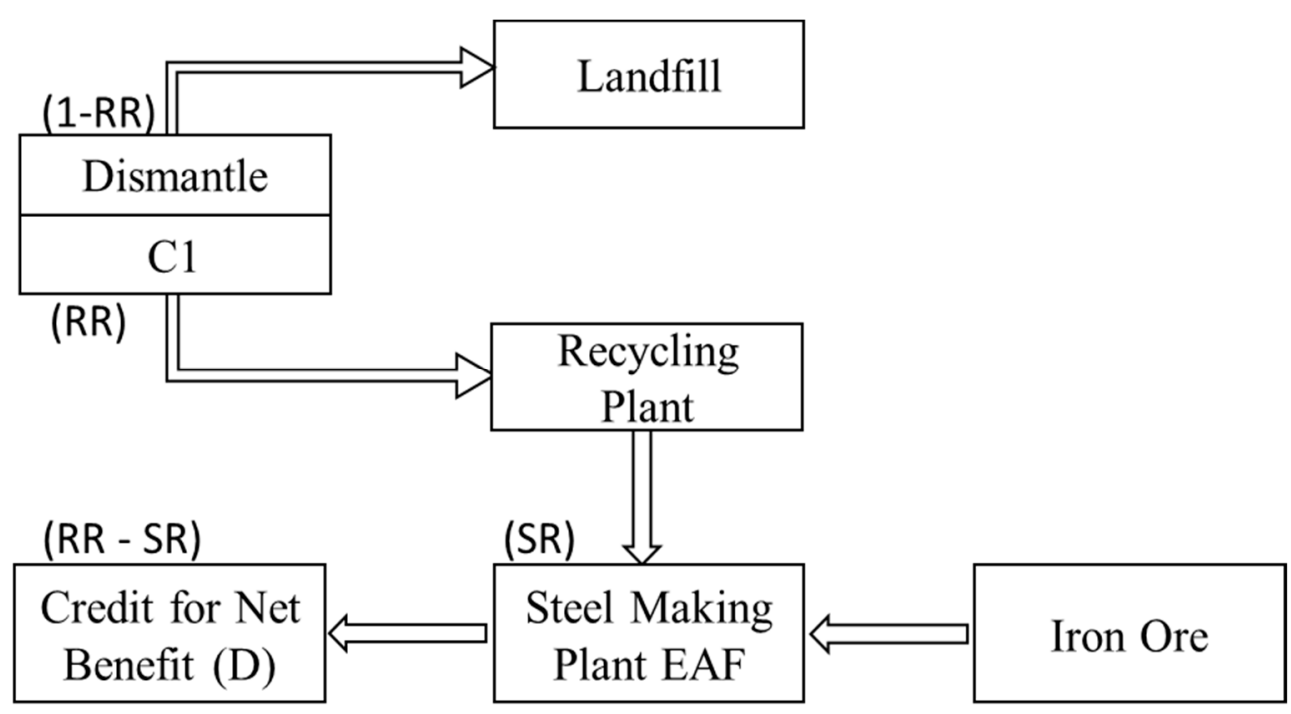

Figure 6. Allocation process flow diagram for recycled steel.

\subsection{Sustainability Assessment}

The results obtained from applying the developed framework to design alternatives can be used to assess the sustainability of each alternative. The following Leadership in Energy and Environmental Design (LEED) credit categories are associated with the selection of the building construction system [39].

\subsubsection{Materials and Resources: Building Life Cycle Impact Reduction}

The main objective of this credit is to promote the adaptive reuse of building materials and products to reduce demand for virgin materials. LEED assigns two, three, or five credit points to building construction systems that display $25 \%, 50 \%$, or $75 \%$ reduction in building material use due to reuse, respectively.

\subsubsection{Materials and Resources: Construction and Demolition Waste Management}

The main objective of this credit is to decrease construction and demolition wastes disposed to landfills by recovering, reusing, and recycling materials. LEED assigns one or two LEED credit points to systems, which redirects $50 \%$ or $75 \%$ of three to four material flows, respectively.

Using the end of life data presented in Sections 4.4 and 4.5, the developed framework can be used to estimate the LEED credit points awarded to each design alternative from those two categories, as demonstrated in the following application.

\section{Case Study: Application}

\subsection{Description of Building}

Use of the developed framework is illustrated through the following application to a university student center, which was constructed at Cairo University in 2017. The completed building is shown in Figure 7. The building built area is square in plan with size equal to $35.86 \mathrm{~m}$ and it has an open square court with a side equal to $20.54 \mathrm{~m}$. The building height is $7 \mathrm{~m}$ and contains two floors. Each floor has an area of $864 \mathrm{~m}^{2}$. The building was constructed using an LSC construction system with a light-reinforced concrete slab for the floors and fiber cement boards for the walls. Two alternative designs shall be studied: reinforced concrete construction system (RCC) and hot-rolled steel construction system 
(HRS). The framework developed in Section 3 was used to calculate the life cycle embodied energy and embodied GHG emissions of the three alternative designs as follows.

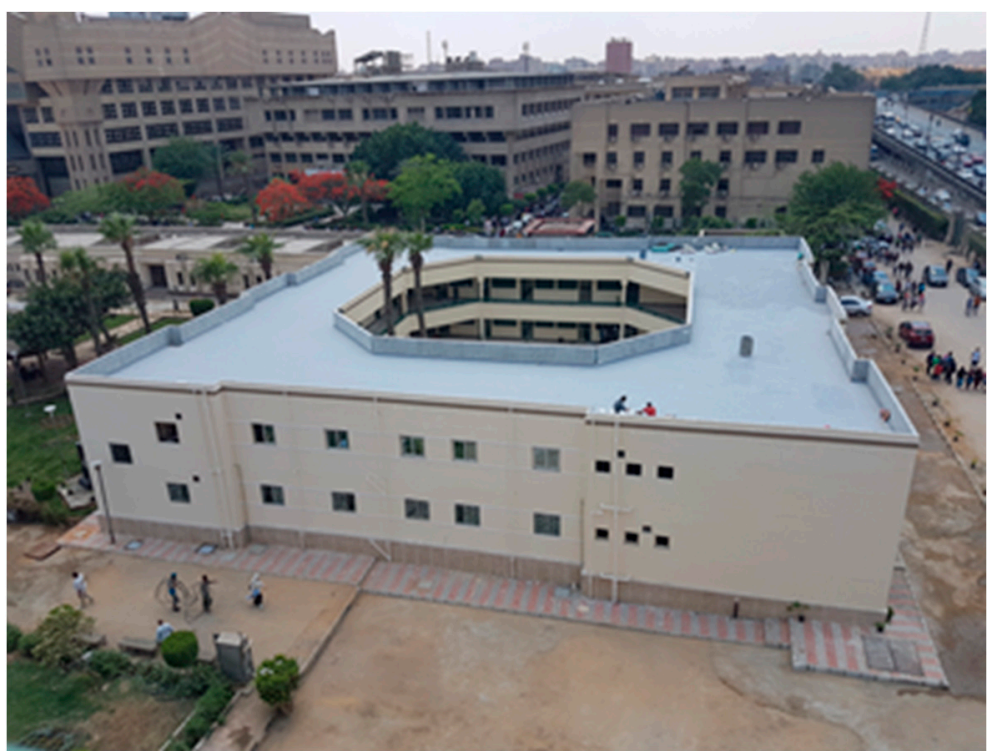

Figure 7. Case study building: student service center at Cairo University.

\subsection{Quantities of Building Materials}

Structural BIM models of the three alternative designs that fulfill the architectural design requirements were constructed. Then, the structural models were imported to the structural analysis and design software [40] to perform the structural analysis and design of the three construction systems. The constructed structural models are shown in Figure 8a for the RCC and HRS construction systems and in Figure 8b for the LCS construction system. The resulting quantities of building material were obtained from the 5D BIM model, as shown in Table 4.

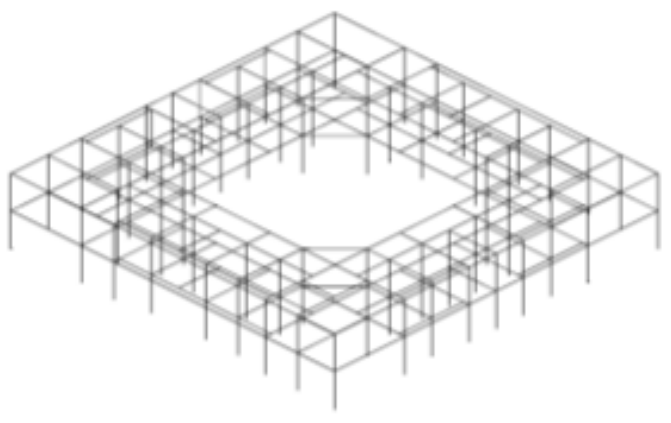

(a) RCC and HRS systems

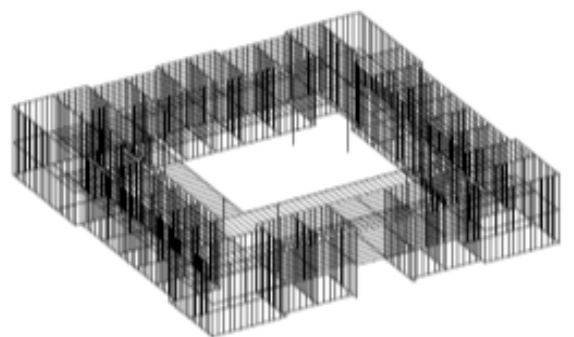

(b) LSC system

Figure 8. Structural Models for reinforced concrete construction (RCC), hot-rolled steel construction (HRS), and light (cold-formed) steel construction system (LSC) framing. 
Table 4. Quantities of building materials for alternative construction systems.

\begin{tabular}{ccccc}
\hline Building Material & UOM & RCC & HRS & LSC \\
\hline Foundation & & & & \\
PC foundation concrete & $\mathrm{m}^{3}$ & 76.904 & 48.328 & 29.956 \\
RC foundation concrete & $\mathrm{m}^{3}$ & 217.02 & 152.46 & 159.1 \\
RC slab on grade concrete & $\mathrm{m}^{3}$ & 172.8 & 172.8 & 172.8 \\
Rebar foundation & ton & 38.982 & 32.526 & 33.91 \\
\hline Superstructure & & & & \\
RC floor concrete & $\mathrm{m}^{3}$ & 230.1 & 230.1 & 86.4 \\
Rebars floor & ton & 23.1 & 13.806 & - \\
RC skeleton & $\mathrm{m}^{3}$ & 211.7 & - & - \\
Re bars skeleton & ton & 21.17 & - & - \\
Welded wire mesh & ton & - & - & 6.938 \\
Galvanized decking & ton & - & 6.912 & - \\
Hot rolled steel sections & ton & - & 110.291 & 54.352 \\
Galvanized studs & ton & - & - & - \\
Wall clay brick & $\mathrm{m}^{3}$ & 509.25 & 509.25 & - \\
Wall mortar & $\mathrm{m}^{3}$ & 81.48 & 81.48 & 4074 \\
Fibercement siding & $\mathrm{m}^{2}$ & - & - & \\
\hline
\end{tabular}

\subsection{Life Cycle Impact Assessment}

The quantities of building materials presented in Section 5.2 and life cycle inventory data presented in Section 4 were used to calculate the embodied energy and embodied GHG emissions at the different life cycle modules from A to D. Details of the calculations are presented in the online Supplementary Data File "Environmental impact calculations.xls." The total life cycle embodied impacts were obtained by summing up the individual contributions of the different modules.

\subsubsection{Life Cycle Embodied Energy}

The embodied energy results for the different life cycle modules are summarized in Figure 9. Detailed calculations of each life cycle module are provided in a Supplementary Data File. Figure 9 shows the comparison of the embodied energy—normalized per square meter of floor area-among the three systems arranged by contribution of life cycle stage in Figure 10a and arranged by the contribution of building group in Figure 10b.

\subsubsection{Life Cycle Embodied GHG Emissions}

The calculations of GHG emissions for the different life cycle modules are summarized in Figure 11. Figure 10 shows the comparison of the GHG emissions-normalized per square meter of floor area-among the three systems arranged by contribution of life cycle stage in Figure 12a and arranged by contribution of building group in Figure 12b. 


\begin{tabular}{|c|c|c|c|c|c|c|c|}
\hline \multirow{2}{*}{ Building Group } & \multirow{2}{*}{ Building Item } & \multirow{2}{*}{$\begin{array}{l}\text { Production } \\
\mathbf{A} 1-\mathbf{A} 3 \\
\end{array}$} & \multicolumn{2}{|c|}{ Construction } & \multicolumn{2}{|c|}{ End of Life } & \multirow{2}{*}{$\begin{array}{l}\text { Recycle } \\
\text { D }\end{array}$} \\
\hline & & & A4 & A5 & C1 & C2 & \\
\hline \multicolumn{8}{|l|}{ RCC } \\
\hline \multirow[t]{2}{*}{ Site Work } & Excavation & & 80.4 & 45.3 & & & \\
\hline & Back filling & & 69.7 & 0.0 & & & \\
\hline \multirow[t]{5}{*}{ Foundations } & PC Foundation concrete & 135.0 & 7.7 & 1.1 & 12.9 & 3.83 & 0 \\
\hline & RC Foundation concrete & 449.2 & 18.4 & 3.1 & 36.5 & 9.96 & 0 \\
\hline & SOG Foundation Concrete & 357.7 & 15.3 & 2.5 & 29.0 & 7.66 & 0 \\
\hline & Reinforcement bars foundations & 467.8 & 1.5 & 0.0 & 2.7 & 1.53 & -327.45 \\
\hline & Foundations Sum= & 1409.7 & 193.0 & 52.0 & 81.1 & 23 & -327.45 \\
\hline \multirow[t]{8}{*}{ Superstructure } & RC Floor concrete & 476.3 & 19.9 & 3.3 & 38.7 & 9.96 & 0 \\
\hline & Reinforcement bars floors & 277.2 & 0.8 & 0.0 & 5.5 & 1.53 & -194.04 \\
\hline & RC Skeleton & 438.2 & 18.4 & 3.0 & 35.6 & 9.19 & 0 \\
\hline & Reinforcement bars Skeleton & 254.0 & 0.8 & 0.0 & 12.1 & 0.77 & -177.83 \\
\hline & Wall Clay Brick & 2068.1 & 22.2 & 0.0 & 57.0 & 22.2 & 0 \\
\hline & Wall Mortar( $2 \mathrm{~cm}$ each side $)$ & 182.6 & 3.8 & 0.0 & 12.5 & 3.83 & 0 \\
\hline & Superstructure Sum= & 3696.5 & 65.9 & 6.3 & 161.5 & 47.5 & -371.87 \\
\hline & SUM= & 5106.2 & 258.8 & 58.4 & 242.6 & 70.45 & -699.32 \\
\hline \multicolumn{8}{|l|}{ HRS } \\
\hline \multirow{2}{*}{ Site Work } & Excavation & & 69.7 & 39.3 & & & \\
\hline & Back filling & & 59.0 & 0.0 & & & \\
\hline \multirow[t]{5}{*}{ Foundations } & PC Foundation concrete & 84.8 & 5.4 & 0.7 & 8.1 & 2.3 & 0.0 \\
\hline & RC Foundation concrete & 315.6 & 13.8 & 2.2 & 25.6 & 6.9 & 0.0 \\
\hline & RC SOG Foundation Concrete & 357.7 & 15.3 & 2.5 & 29.0 & 7.7 & 0.0 \\
\hline & Rebars & 390.3 & 2.3 & 0.0 & 2.3 & 1.5 & -273.2 \\
\hline & Foundations Sum= & 1148.4 & 165.4 & 44.7 & 65.0 & 18.4 & -273.2 \\
\hline \multirow[t]{8}{*}{ Superstructure } & RC Floor concrete & 476.3 & 19.9 & 3.3 & 38.7 & 10.0 & 0.0 \\
\hline & Rebars & 165.7 & 0.8 & 0.0 & 1.0 & 0.8 & -116.0 \\
\hline & Galvanized Decking for floors & 231.2 & 0.8 & 0.0 & 0.5 & 0.8 & -208.1 \\
\hline & Hot rolled steel Sections & 3296.6 & 3.1 & 4.2 & 26.4 & 3.1 & -2966.9 \\
\hline & Wall clay Brick & 2068.1 & 22.2 & 0.0 & 55.3 & 22.2 & 0.0 \\
\hline & Wall Mortar & 182.6 & 3.8 & 0.0 & 12.5 & 3.8 & 0.0 \\
\hline & Superstructure Sum= & 6420.5 & 50.5 & 7.5 & 134.3 & 40.6 & -3291.0 \\
\hline & SUM= & 7568.9 & 216.0 & 52.2 & 199.3 & 59.0 & -3564.2 \\
\hline \multicolumn{8}{|l|}{ LSC } \\
\hline \multirow[t]{2}{*}{ Site Work } & Excavation & & 53.606 & 30.22 & & & \\
\hline & Back filling & & 49.0112 & 0 & & & \\
\hline \multirow[t]{5}{*}{ Foundations } & PC Foundation concrete & 52.57278 & 3.829 & 0.43 & 5.0326 & 1.53 & 0 \\
\hline & RC Foundation concrete & 329.337 & 6.1264 & 0.78 & 26.729 & 3.06 & 0 \\
\hline & SOG Foundation concrete & 357.696 & 15.316 & & 29.03 & 7.66 & 0 \\
\hline & Reinforcing bars & 406.92 & 3.0632 & 2.481 & 2.3737 & 1.53 & -284.84 \\
\hline & Foundations Sum= & 1146.5258 & 130.952 & 33.91 & 63.166 & 13.8 & -284.84 \\
\hline \multirow[t]{7}{*}{ Superstructure } & Galvanized studs & 1585.4478 & 3.0632 & 0 & 12.99 & 3.83 & -1426.9 \\
\hline & Galvanized decking & 231.19258 & 0.7658 & 0 & 1.652 & 0.77 & -208.07 \\
\hline & Welded wire mesh & 59.647702 & 0.7658 & 0 & 1.1563 & 0.77 & -53.683 \\
\hline & Floor concrete & 178.848 & 8.4238 & 1.241 & 14.515 & 3.06 & 0 \\
\hline & Fibercement siding & 293.328 & 2.2974 & 0 & 3.4222 & 2.3 & -205.33 \\
\hline & Superstructure Sum= & 2348.4641 & 15.316 & 1.241 & 33.736 & 10.7 & -1894 \\
\hline & SUM= & 3494.9899 & 146.268 & 35.15 & 96.901 & 24.5 & -2178.8 \\
\hline
\end{tabular}

Figure 9. Life cycle embodied energy (GJ). 


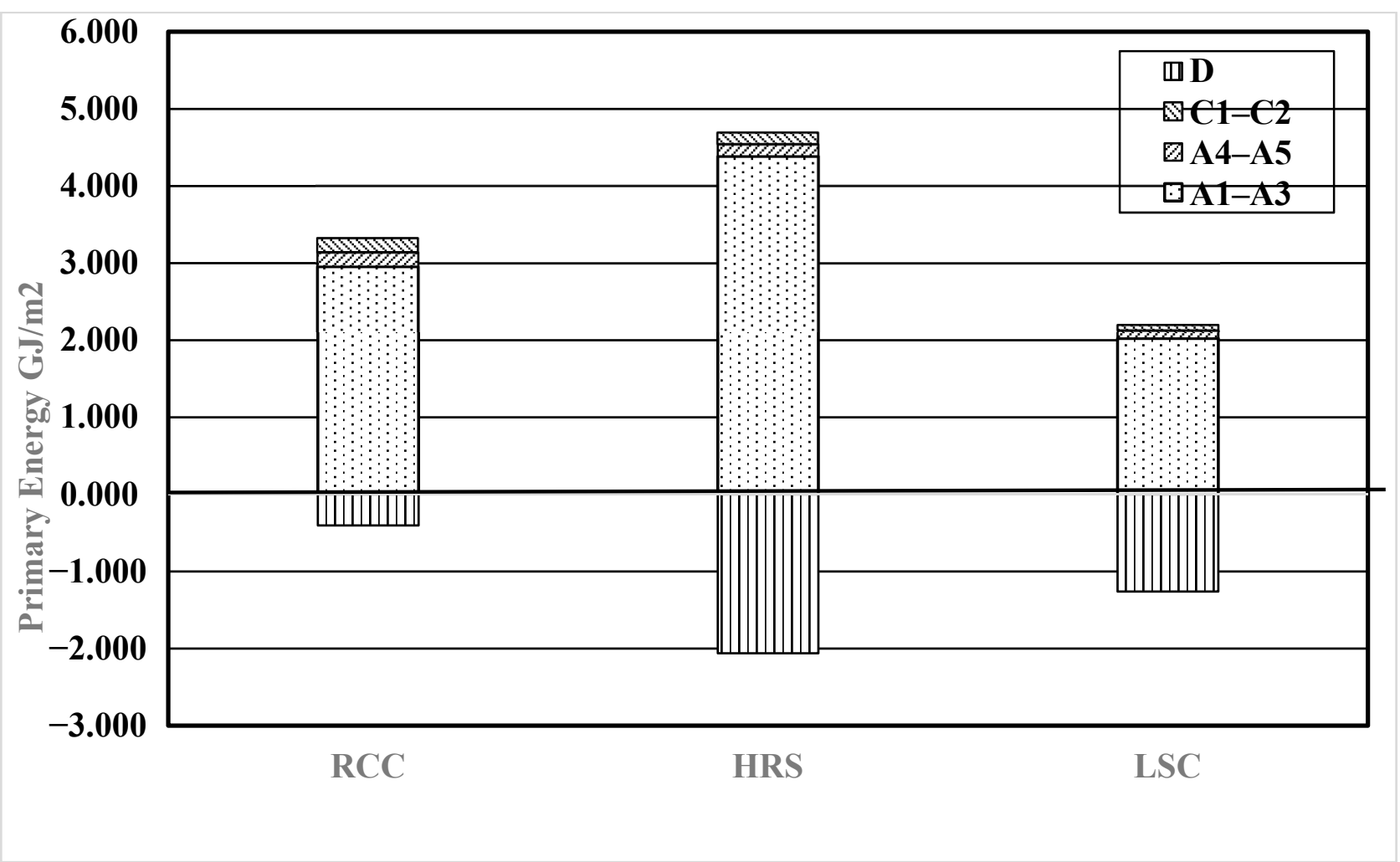

(a) Comparison by life cycle stage

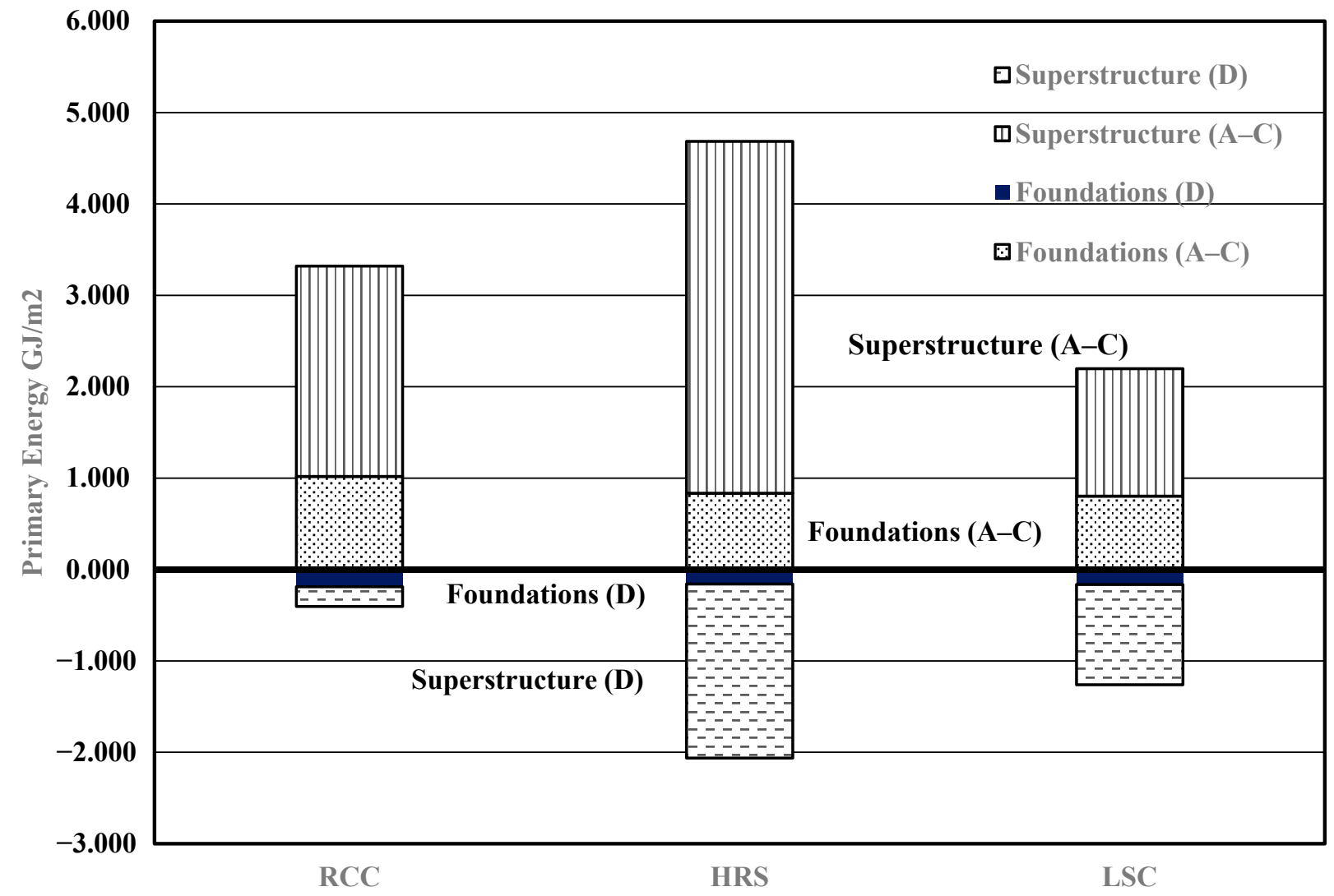

(b) Comparison by building component

Figure 10. Comparison of normalized life cycle embodied energy for the three construction systems. 


\begin{tabular}{|c|c|c|c|c|c|c|c|}
\hline \multirow{2}{*}{ Building Group } & \multirow{2}{*}{ Building Item } & \multirow{2}{*}{$\begin{array}{c}\text { Production } \\
\mathbf{A 1}-\mathbf{A 3} \\
\end{array}$} & \multicolumn{2}{|c|}{ Construction } & \multicolumn{2}{|c|}{ End of Life } & \multirow{2}{*}{$\frac{\text { Recycle }}{\text { D }}$} \\
\hline & & & $\mathbf{A 4}$ & A5 & C1 & $\mathrm{C2}$ & \\
\hline \multicolumn{8}{|l|}{ RCC } \\
\hline \multirow[t]{2}{*}{ Site Work } & Excavation & & 6.65 & 3.75 & & & \\
\hline & Back filling & & 5.77 & 0.00 & & & \\
\hline \multirow[t]{5}{*}{ Foundations } & PC Foundation concrete & 19.61 & 0.63 & 0.09 & 1.07 & 0.32 & 0.00 \\
\hline & RC Foundation concrete & 72.70 & 1.52 & 0.26 & 3.02 & 0.82 & 0.00 \\
\hline & SOG Foundation Concrete & 57.89 & 1.27 & 0.21 & 2.40 & 0.63 & 0.00 \\
\hline & Reinforcement bars foundations & 34.73 & 0.13 & 0.00 & 0.23 & 0.13 & -24.31 \\
\hline & Foundations Sum= & 184.93 & 15.96 & 4.30 & 6.71 & 1.90 & -24.31 \\
\hline \multirow[t]{8}{*}{ Superstructure } & RC Floor concrete & 77.08 & 1.65 & 0.27 & 3.20 & 0.82 & 0.00 \\
\hline & Reinforcement bars floors & 20.58 & 0.06 & 0.00 & 0.46 & 0.13 & -14.41 \\
\hline & RC Skeleton & 70.92 & 1.52 & 0.25 & 2.94 & 0.76 & 0.00 \\
\hline & Reinforcement bars Skeleton & 18.86 & 0.06 & 0.00 & 1.00 & 0.06 & -13.20 \\
\hline & Wall Clay Brick & 146.15 & 1.84 & 0.00 & 4.72 & 1.84 & 0.00 \\
\hline & Wall Mortar( $2 \mathrm{~cm}$ each side $)$ & 27.77 & 0.32 & 0.00 & 1.04 & 0.32 & 0.00 \\
\hline & Superstructure Sum= & 361.37 & 5.45 & 0.52 & 13.36 & 3.93 & -27.61 \\
\hline & SUM= & 546.30 & 21.41 & 4.83 & 20.07 & 5.83 & -51.92 \\
\hline \multicolumn{8}{|l|}{ HRS } \\
\hline \multirow[t]{2}{*}{ Site Work } & Excavation & & 5.77 & 3.25 & & & \\
\hline & Back filling & & 4.88 & 0.00 & & & \\
\hline \multirow{5}{*}{ Foundations } & PC Foundation concrete & 12.32 & 0.44 & 0.06 & 0.67 & 0.19 & 0.00 \\
\hline & RC Foundation concrete & 51.07 & 1.14 & 0.18 & 2.12 & 0.57 & 0.00 \\
\hline & RC SOG Foundation Concrete & 57.89 & 1.27 & 0.21 & 2.40 & 0.63 & 0.00 \\
\hline & Rebars & 28.98 & 0.19 & 0.00 & 0.19 & 0.13 & -20.29 \\
\hline & Foundations Sum= & 150.27 & 13.68 & 3.69 & 5.38 & 1.52 & -20.29 \\
\hline \multirow{8}{*}{ Superstructure } & RC Floor concrete & 77.08 & 1.65 & 0.27 & 3.20 & 0.82 & 0.00 \\
\hline & Rebars & 12.30 & 0.06 & 0.00 & 0.08 & 0.06 & -8.61 \\
\hline & Galvanized Decking for floors & 11.67 & 0.06 & 0.00 & 0.04 & 0.06 & -10.51 \\
\hline & Hot rolled steel Sections & 298.89 & 0.25 & 0.35 & 2.18 & 0.25 & -269.00 \\
\hline & Wall clay Brick & 146.15 & 1.84 & 0.00 & 4.57 & 1.84 & 0.00 \\
\hline & Wall Mortar & 27.77 & 0.32 & 0.00 & 1.04 & 0.32 & 0.00 \\
\hline & Superstructure Sum = & 573.87 & 4.18 & 0.62 & 11.11 & 3.36 & -288.12 \\
\hline & SUM= & 724.14 & 17.87 & 4.32 & 16.49 & 4.88 & -308.40 \\
\hline \multicolumn{8}{|l|}{ LSC } \\
\hline \multirow[t]{2}{*}{ Site Work } & Excavation & & 4.43 & 2.50 & & & \\
\hline & Back filling & & 4.05 & 0.00 & & & \\
\hline \multirow[t]{5}{*}{ Foundations } & PC Foundation concrete & 7.64 & 0.32 & 0.04 & 0.42 & 0.13 & 0.00 \\
\hline & RC Foundation concrete & 53.30 & 0.51 & 0.06 & 2.21 & 0.25 & 0.00 \\
\hline & SOG Foundation concrete & 57.89 & 1.27 & 0.00 & 2.40 & 0.63 & 0.00 \\
\hline & Reinforcing bars & 30.21 & 0.25 & 0.21 & 0.20 & 0.13 & -21.15 \\
\hline & Foundations Sum= & 149.04 & 10.83 & 2.81 & 5.23 & 1.14 & -21.15 \\
\hline \multirow[t]{7}{*}{ Superstructure } & Galvanized studs & 123.92 & 0.25 & 0.00 & 1.07 & 0.32 & -111.53 \\
\hline & Galvanized decking & 11.67 & 0.06 & 0.00 & 0.14 & 0.06 & -10.51 \\
\hline & Welded wire mesh & 3.57 & 0.06 & 0.00 & 0.10 & 0.06 & -2.50 \\
\hline & Floor concrete & 28.94 & 0.70 & 0.10 & 1.20 & 0.25 & 0.00 \\
\hline & Fibercement siding & 35.85 & 0.19 & 0.00 & 0.28 & 0.19 & -25.10 \\
\hline & Superstructure Sum= & 203.96 & 1.27 & 0.10 & 2.79 & 0.89 & -149.63 \\
\hline & SUM= & 353.00 & 12.10 & 2.91 & 8.02 & 2.03 & -170.78 \\
\hline
\end{tabular}

Figure 11. Embodied GHG emissions (ton $\mathrm{CO}_{2} \mathrm{eq}$ ). 


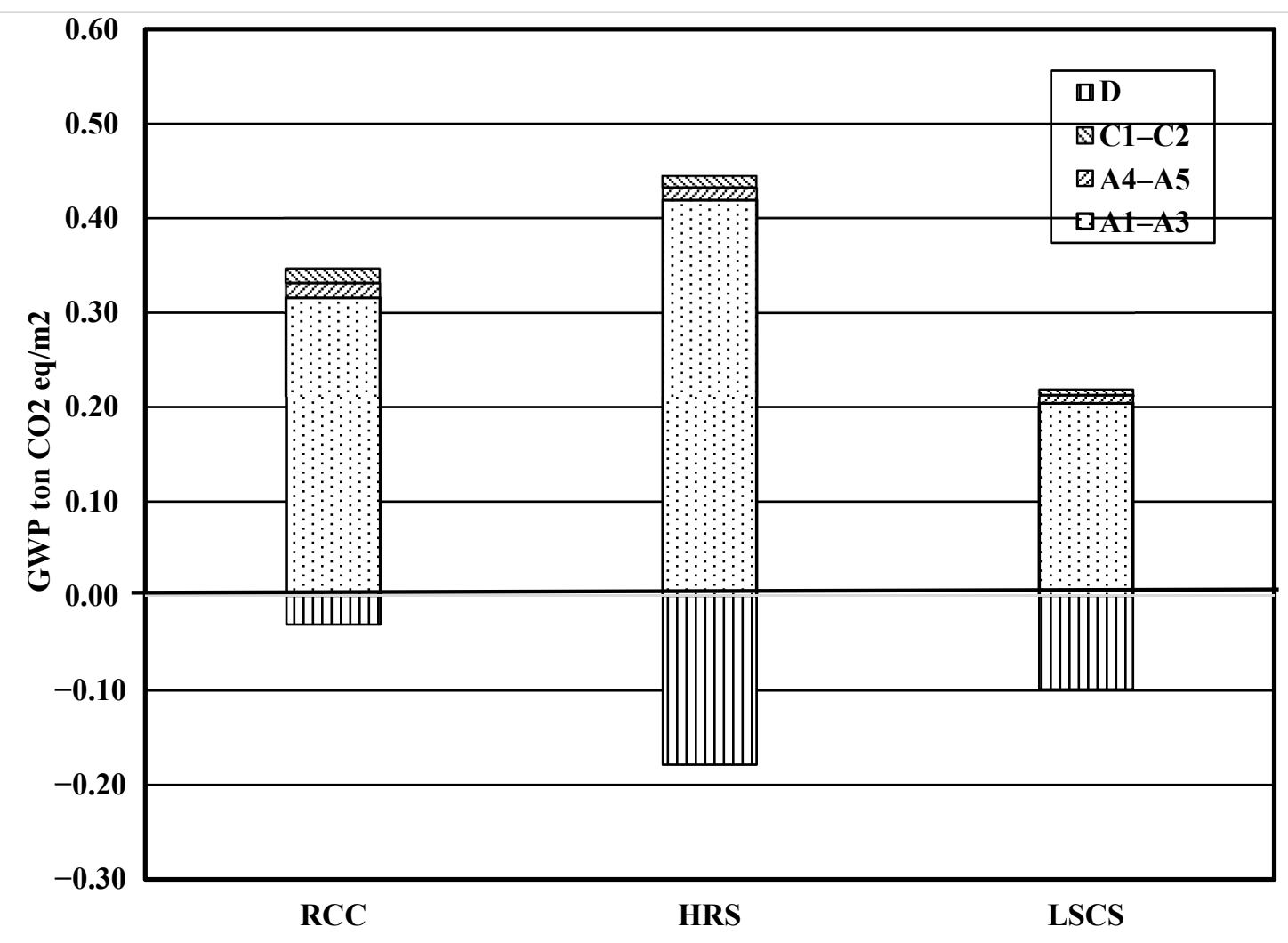

(a) Comparison by life cycle stage.

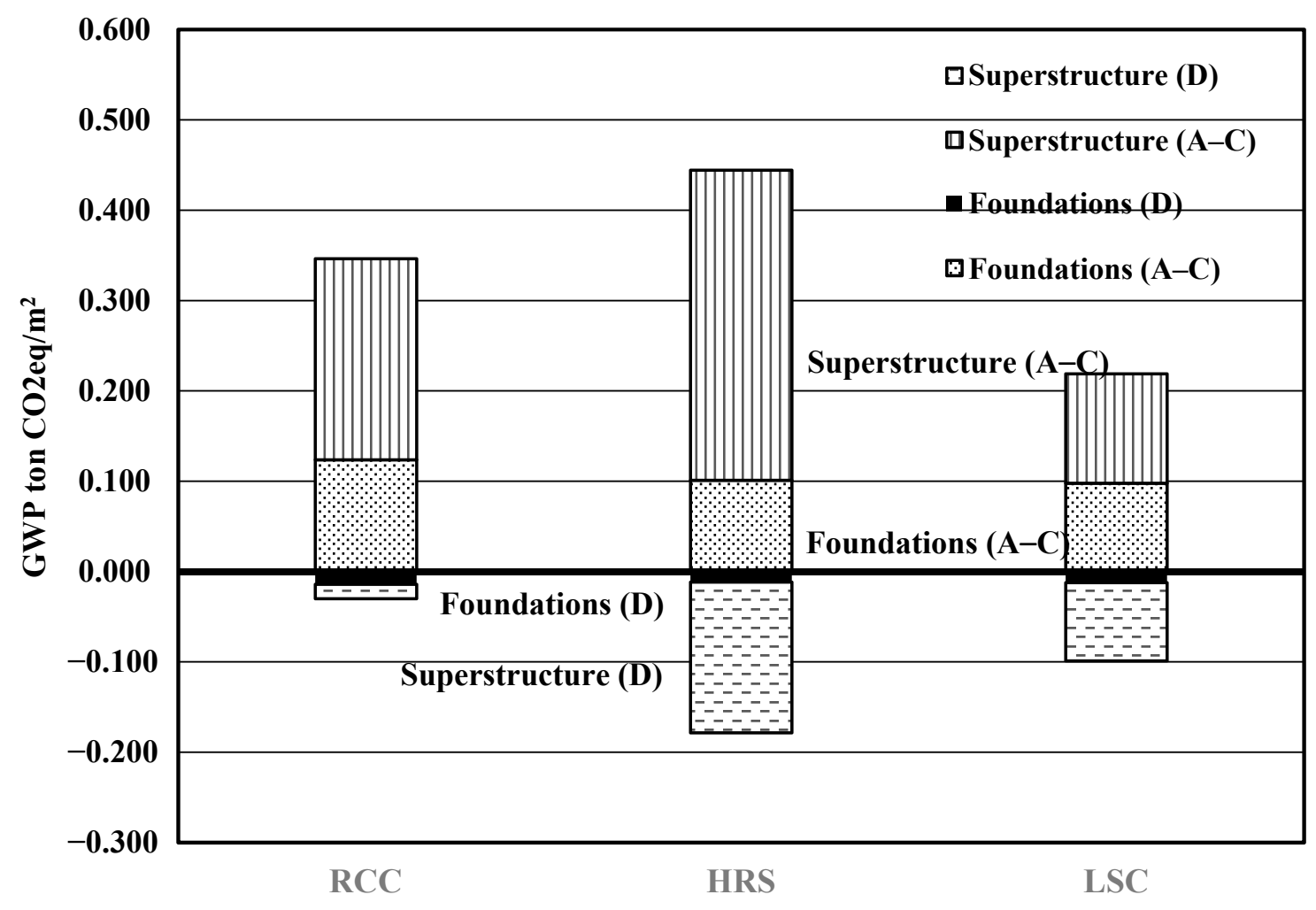

(b) Comparison by building component.

Figure 12. Comparison of normalized life cycle GHG emissions for three construction systems. 


\section{Discussion of Results}

\subsection{Life Cycle Embodied Energy}

(a) Comparison with benchmark results: The life cycle embodied energy (Modules A to C) is equal to $3.32 \mathrm{GJ} / \mathrm{m}^{2}$ for the RCC system, 4.684 for the HRS system, and $2.198 \mathrm{GJ} / \mathrm{m}^{2}$ for the LSC system. Typical benchmark results are $5-11.6 \mathrm{GJ} / \mathrm{m}^{2}$ reported by [41] based on analyzing 80 buildings all over the world and $9 \mathrm{GJ} / \mathrm{m}^{2}$ reported by Gervasio et al. [42] based on analyzing 76 buildings in Europe.

(b) Comparison by construction system: Compared with the conventional RCC system, the HRS system has $41 \%$ more life cycle embodied energy, while the LSC system has $34 \%$ less life cycle embodied energy.

(c) Embodied to operational energy: The operational energy over a 50-year design life of the same building was calculated using energy simulation as detailed in Abouhamad and Abu-Hamd [10]. The operational energy was found to be nearly the same for all three building systems at $31.60 \mathrm{GJ} / \mathrm{m}^{2}$. The ratio of embodied energy to operational energy is equal to $10.5 \%$ for the RCC system, $14.83 \%$ for the HRS system, and $6.96 \%$ for the LSC system. Typical benchmark results are 6-20\% reported by Chastas et al. [21] based on an analysis of 90 residential buildings.

(d) Added benefits from Module D: The added net benefits from Module D reach 12.2\% for the RCC system, 44\% for the HRS system, and 57.4\% for the LSC system. When each system is credited with these net benefits, the LSC system has the least whole life cycle embodied energy followed by the HRS system and the RCC system. This is attributed to the light-weight design of LSC systems in addition to the benefits given to the system from Module D due to recycling of steel members and reuse of ferrocement wall boards. These results show that material recycling/reuse reduced the embodied energy by $12 \%$ for the RCC system, $44 \%$ for the HRS system, and $57 \%$ for LSC framing.

(e) Comparison by life cycle stage:

- The material production stage (Modules A1 to A3) has the highest contribution to embodied energy as it represents $89 \%$ for the RCC system, $93.5 \%$ for the HRS system, and $92 \%$ for the LSC system.

- The contribution of the construction stage (Modules A4 and A5) is 5.5\% for the RCC system, 3.3\% for the HRS system, and $4.8 \%$ for the LSC system.

- The contribution of the end-of-life stage (Modules C1 and C2) is 5.5\% for the RCC system, $3.2 \%$ for the HRS system, and 3.2\% for the LSC system.

- The contribution of substructure (site work and foundations) to the life cycle embodied energy is $30.7 \%$ for the RCC system, $17.8 \%$ for the HRS system, and $36.6 \%$ for the LSC system.

\subsection{Life Cycle GHG Emissions}

(a) Comparison with available benchmark results: The life cycle GHG emissions (Modules A to C) expressed in ton $\mathrm{CO}_{2} \mathrm{eq} / \mathrm{m}^{2}$ is equal to 0.346 for the RCC system, 0.444 for the HRS system, and 0.219 for the LSC system. Typical benchmark results are $0.867 \mathrm{t} \mathrm{CO} \mathrm{CO}_{2} / \mathrm{m}^{2}$ for office buildings and $0.337 \mathrm{t} \mathrm{CO}_{2} \mathrm{eq} / \mathrm{m}^{2}$ for residential buildings for a 50-year design life reported by Rock et al. [23] based on the analysis of more than 650 life cycle assessment case studies, $0.3-0.9 \mathrm{t} \mathrm{CO}_{2} \mathrm{eq} / \mathrm{m}^{2}$ reported by the IEA [41] based on analyzing 80 buildings all over the world, and $0.85 \mathrm{tCO}_{2} \mathrm{eq} / \mathrm{m}^{2}$ reported by Gervasio et al. [42] based on analyzing 76 buildings in Europe.

(b) Comparison by construction system: Compared with the conventional RCC system, the HRS system has $28 \%$ more life cycle GHG emissions, while the LSC system has $37 \%$ less life cycle GHG emissions.

(c) Added benefits from Module D: The added net benefits from Module D are equal to $8.7 \%$ for the RCC system, $40.2 \%$ for the HRS system, and $45.2 \%$ for the LSC system. When each system is credited with these net benefits, the LSC system has the least whole life cycle GHG emissions followed by the HRS system and RCC system. This 
is attributed to the light-weight design of LSC systems in addition to the benefits given to the system from Module D due to the recycling of steel members and reuse of ferrocement wall boards. These results show that material recycling/reuse reduced the embodied GHG emissions by $9 \%$ for the RCC system, $49 \%$ for the HRS system, and $44 \%$ for the LSC system.

(d) Comparison by life cycle stage:

- The material production stage (Modules A1 to A3) has the highest contribution to GHG emissions as it represents $91.3 \%$ for the RCC system, $94.3 \%$ for the HRS system, and $93.4 \%$ for the LSC system.

- The contribution of the construction stage (Modules A4 and A5) is $4.4 \%$ for the RCC system, 2.9\% for the HRS system, and $4.0 \%$ for the LSC system.

- The contribution of the end-of-life stage (Modules C1 and C2) is $4.3 \%$ for the RCC system, 2.8\% for the HRS system, and $2.65 \%$ for the LSC system.

- The contribution of substructure (site work and foundations) to the life cycle GHG emissions is $35.7 \%$ for the RCC system, $22.7 \%$ for the HRS system, and $44.7 \%$ for the LSC system.

\subsection{Sustainability Assessment}

\subsubsection{LEED Credit Points from Reduction of Building Life Cycle Impact}

The benefits in Module D from recycle/reuse is $12.2 \%$ for the RCC construction system, which results in no LEED credit points, $44 \%$ for the HRS construction system, which results in two LEED credit points, and $57.2 \%$ for the LSC construction system, which results in three LEED credit points.

\subsubsection{LEED Credit Points from Construction and Demolition Waste Management}

In the RCC construction system, only steel reinforcement can be diverted to be used as scrap steel in recycling. The system does not get any credit points from this category since the percentage of the completed project surface area reused is less than $25 \%$. In the HRS construction system, steel reinforcement, hot-rolled steel members, and metal decking can be diverted for recycling (more than $50 \%$ ), which is worth one credit point. In the LSC construction system, steel reinforcement and light gauge steel are used as scrap steel in recycling, while fiber cement wall boards can be diverted to be reused. These elements represent more than $75 \%$, which is worth two credit points.

The final sustainability assessment result is that the RCC construction system gets zero LEED credit points, the HRS construction system gets three LEED credit points, while the LSC construction system gets five LEED credit points.

\section{Conclusions}

An LCA framework for embodied energy and embodied GHG emissions of building construction systems have been developed. The framework is intended to be used early in the design stage to assist decision making in identifying sources of higher embodied impacts and in selecting sustainable design alternatives. The framework is developed in accordance with the relevant international LCA guidelines. The system boundary is from cradle to grave in addition to net loads and benefits from possible recycling/reuse. The life cycle inventory data used to develop the framework were extracted from BIM models for the material quantities, from verified EPDs for the material production stage, and from thedesign of construction operations for the construction and end-of-life stages. Application of the developed framework to a university building revealed the following results. The material production stage had the highest contribution to embodied impacts, reaching about $90 \%$ for all three systems. Substructure building elements contributed $30.7-35.7 \%, 17.8-22.7 \%$, and $36.6-44.7 \%$ of embodied impacts for the RCC system, HRS system, and LSC system, respectively. The LSC system had the least embodied impacts, followed by the RCC system and HRS system. Compared with the conventional RCC system, the HRS system had 41\% more life cycle embodied energy while the LSC system 
had 34\% less life cycle embodied energy. When each system was credited with the net benefits resulting from possible recycling/reuse in Module D, the LSC system had the least whole life cycle embodied impacts followed by the RCC system and the HRS system. With Module D included, the HRS system had 10-29\% less life cycle embodied impact than the RCC system, while the LSC system had $62-68 \%$ less life cycle embodied impact than the RCC system. Material recycling/reuse reduced the embodied impacts by $9-12 \%$ for the RCC system, $44-49 \%$ for the HRS system, and $44-57 \%$ for the LSC system. LCA results obtained from the developed framework were used to assess the sustainability of the design alternatives, which showed that RCC systems received zero LEED credit points, HRS framing received three LEED credit points, while LSC framing received five LEED credit points.

Supplementary Materials: The following is available online at https:/ /www.mdpi.com/2071-1050/ 13/2/461/s1, Environmental impact calculations.xls.

Author Contributions: Conceptualization, M.A. and M.A.-H.; methodology, M.A.; software, M.A.; validation, M.A. and M.A.-H.; formal analysis, M.A.; investigation, M.A.; resources, M.A.; data curation, M.A.; writing—original draft preparation, M.A.; writing—review and editing, M.A. and M.A.-H.; visualization, M.A.; supervision, M.A.; project administration, M.A. and M.A.-H. All authors have read and agreed to the published version of the manuscript.

Funding: This research received no external funding.

Conflicts of Interest: The authors declare no conflict of interest.

\section{References}

1. IPCC. Summary for policymakers. In Global Warming of $1.5^{\circ} \mathrm{C}$. An IPCC Special Report on the Impacts of Global Warming of $1.5^{\circ} \mathrm{C}$ above Pre-Industrial Levels and Related Global Greenhouse Gas Emission Pathways; Masson-Delmotte, P., Zhai, H.O., Pörtner, D., Roberts, J., Skea, P.R., Shukla, A., Pirani, W., Moufouma-Okia, C., Péan, R., Pidcock, S., Eds.; World Meteorological Organization: Geneva, Switzerland, 2018; p. 32.

2. GABC Global Alliance for Buildings and Construction. International Energy Agency and the United Nations Environment Program: 2019 Global Status Report for Buildings and Construction: Towards a Zero-Emission, Efficient and Resilient Buildings and Construction Sector; United Nations Environment Program: Nairobi, Kenya, 2019.

3. EBC Evaluation of Embodied Energy and CO2eq for Building Construction (Annex 57), Energy in Buildings and Communities Program, International Energy Agency. 2016. Available online: http:/ /www.iea-ebc.org/Data/publications/EBC_Annex_57 _Results_Overview.pdf (accessed on 6 December 2020).

4. CIF Climate Investment Funds: Egypt. 2020. Available online: https://www-cif.climateinvestmentfunds.org/country/egypt (accessed on 6 December 2020).

5. CAIT Total GHG Emissions Including Land-Use and Forestry, MENA. World Resources Institute. CAIT Climate Data Explorer. 2018. Available online: http:/ / cait.wri.org (accessed on 18 May 2020).

6. United Nations. Report of the Conference of the Parties on its twenty-first session, held in Paris from 30 November to 13 December 2015. In United Nations Framework Convention on Climate Change; Available online: https:/ / unfccc.int/resource/docs/ 2015/cop21/eng/10.pdf (accessed on 6 December 2020).

7. European Commission. Roadmap to a Resource Efficient Europe; Communication from the Commission to the European Parliament, the Council, The European Economic and Social Committee and the Committee of the Regions; European Commission: Brussels, Belgium, 2011.

8. IPCC. Special Report Global Warming of $1.5^{\circ} \mathrm{C}$. In Intergovernmental Panel on Climate Change; Masson-Delmotte, V., Zhai, P., Portner, H.O., Eds.; The United Nations: Herndon, VA, USA, 2018.

9. United Nations. Transforming Our World: The 2030 Agenda for Sustainable Development. 2015. Available online: https: //sustainabledevelopment.un.org/post2015/transformingourworld/publication (accessed on 18 April 2020).

10. Abouhamad, M.; Abu-Hamd, M. Framework for construction system selection based on life cycle cost and sustainability assessment. J. Clean. Prod. 2019, 241, 118397. [CrossRef]

11. Abouhamad, M.; Abu-Hamd, M. Life cycle cost analysis of light steel framed buildings with cement-based walls and floors. In Proceedings of the Canadian Society of Civil Engineers Annual Conference, Montreal, QC, Canada, 12-15 June 2019. paper CON-82.

12. Abouhamad, M.; Abu-Hamd, M. Life cycle environmental assessment of light steel framed buildings with cement-based walls and floors. Sustainability 2020, 12, 10686. [CrossRef]

13. EBC Assessing Life Cycle Related Environmental Impacts Caused by Buildings (Annex 72). Energy in Buildings and Communities Program, International Energy Agency. 2020. Available online: http:/ /annex72.iea-ebc.org/ (accessed on 18 April 2020). 
14. ISO 14040: 2006. Environmental Management_Life Cycle Assessment_Principles and Framework; International Organization for Standardization (ISO): Geneva, Switzerland, 2006.

15. ISO 14044: 2006. Environmental Management_Life Cycle Assessment_Requirements and Guidelines; International Organization for Standardization (ISO): Geneva, Switzerland, 2006.

16. EN 15978:2011. Sustainability of Construction Works—Assessment of Environmental Performance of Buildings—Calculation Method; European Standard: Brussels, Belgium, 2011.

17. EN 15804:2014. Sustainability of Construction Works—Environmental Product Declarations_Core Rules for Product Category of Construction Products; European Standard: Brussels, Belgium, 2012.

18. Zeng, R.; Chini, A. A review of research on embodied energy of buildings using bibliometric analysis. Energy Build. 2017, 155, 172-184. [CrossRef]

19. Dixit, M.K. Life cycle embodied energy analysis of residential buildings: A review of literature to investigate embodied energy parameters. Renew. Sustain. Energy Rev. 2017, 79, 390-413. [CrossRef]

20. de Wolf, C.; Pomponi, F.; Moncaster, A. Measuring embodied carbon dioxide equivalent of buildings: A review and critique of current industry practice. Energy Build. 2017, 140, 68-80. [CrossRef]

21. Chastas, P.; Theodosiou, T.; Kontoleon, K.J.; Bikas, D. Normalizing and assessing carbon emissions in the building sector: A review on the embodied CO2 emissions of residential buildings. Build. Environ. 2018, 130, 212-226. [CrossRef]

22. Fenner, A.E.; Kibert, C.J.; Woo, J.; Morque, S.; Razkenari, M.; Hakim, H.; Lu, X. The carbon footprint of buildings: A review of methodologies and applications. Renew. Sustain. Energy Rev. 2018, 94, 1142-1152. [CrossRef]

23. Röck, M.; Saade, M.R.M.; Balouktsi, M.; Rasmussen, F.N.; Birgisdottir, H.; Frischknecht, R.; Habert, G.; Lützkendorf, T.; Passer, A. Embodied GHG emissions of buildings-The hidden challenge for effective climate change mitigation. Appl. Energy 2020, 258, 114107. [CrossRef]

24. Birgisdottir, H.; Moncaster, A.; Wiberg, A.H.; Chae, C.; Yokoyama, K.; Balouktsi, M.; Seo, S.; Oka, T.; Lützkendorf, T.; Malmqvist, T. IEA EBC annex 57 'evaluation of embodied energy and CO2eq for building construction'. Energy Build. 2017, 154, 72-80. [CrossRef]

25. Simonen, K.; Rodriguez, B.; McDade, E.; Strain, L. Embodied carbon benchmark study: LCA for low carbon construction. 2017. Available online: http:/ / hdl.handle.net/1773/38017 (accessed on 18 April 2020).

26. Gervasio, H.; Dimova, S. Model for Life Cycle Assessment (LCA) of Buildings; EUR 29123 EN; Publications Office of the European Union: Luxembourg, 2018; ISBN 978-92-79-79973-0. Available online: Publications.jrc.ec.europa.eu (accessed on 20 April 2020). [CrossRef]

27. Rodrigues, V.; Martins, A.A.; Nunes, M.I.; Quintas, A.; Mata, T.M.; Caetano, N.S. LCA of constructing an industrial building: Focus on embodied carbon and energy. Energy Procedia 2018, 153, 420-425. [CrossRef]

28. Nwodo, M.N.; Anumba, C.J. A review of life cycle assessment of buildings using a systematic approach. Build. Environ. 2019, 162, 106290. [CrossRef]

29. EN 1990:2002. Eurocode_-Basis of Structural Design; European Standard: Brussels, Belgium, 2002.

30. Abu-Hamd, M.; Atef, D.; Masoud, M. Application of 4D and 5D BIM in cold formed steel residential buildings. In Proceedings of the 5th International Structural Specialty Conference, Canadian Society for Civil Engineering, London, ON, Canada, 8-11 June 2016. STR-862-1-10.

31. Worldsteel Association. Life Cycle Assessment Methodology Report. 2011. Available online: https://www.worldsteel.org (accessed on 18 April 2020).

32. ISO 14025:2006. Environmental Labels and Declarations-Type III Environmental Declarations_Principles and Procedures; International Organization for Standardization: Geneva, Switzerland, 2006.

33. ED. The International EDP System. 2020. Available online: https://www.environdec.com/ (accessed on 18 April 2020).

34. ERA. Electricity Production and Consumption Data. 2020. Available online: https:/ / egyptera.org. (accessed on 18 April 2020).

35. IPCC. IPCC Guidelines for National Greenhouse Gas Inventories. In Volume 2: Energy. Prepared by the National Greenhouse Gas Inventories Program; Eggleston, H.S., Buendia, L., Miwa, K., Ngara, T., Tanabe, K., Eds.; Intergovernmental Panel on Climate Change: Geneva, Switzerland, 2006.

36. Dixit, M.K. Life cycle recurrent embodied energy calculation of buildings: A review. J. Clean. Prod. 2019, 209, 731-754. [CrossRef]

37. SMI. Demolition Energy Analysis of Office Building Systems; Athena Sustainable Materials Institute: Ottawa, ON, Canada, 1997.

38. EU Directive 2008/98/EC of the European Parliament. Available online: http:/ /ec.europa.eu/environment/circular-economy/ index_en.htm (accessed on 18 April 2020).

39. U.S. Green Building Counci. LEED v4 for Building Design and Construction; US Green Building Council: Washington, DC, USA, 2019.

40. STAAD PRO 3D Structural Analysis and Design Software, Bentley. Available online: www.bentley.com. (accessed on 18 April 2020).

41. IEA (International Energy Agency). Evaluation of Embodied Energy and CO2 eq. for Building Construction (Annex 57)—Subtask 4: Case Studies and Recommendations for the Reduction of Embodied Energy and Embodied Greenhouse Gas Emissions from Buildings; Institute for Building Environment and Energy Conservation: Tokyo, Japan, 2016.

42. Gervasio, H.; Dimova, S.; Pinto, A. Benchmarking the life-cycle environmental performance of buildings. Sustainability 2018, 10, 1454. [CrossRef] 